\begin{tabular}{c} 
Tersedia online di: http://ejournal-balitbang.kkp.go.id/index.php/bawal \\
e-mail:bawal.puslitbangkan@ gmail.com \\
BAWAL WIDYA RISET PERIKANAN TANGKAP \\
Volume 11 Nomor 2 Agustus 2019 \\
p-ISSN: 1907-8226 \\
e-ISSN: 2502-6410 \\
BAWAL \\
Nomor Akreditasi Kementerian RISTEKDIKTI: 21/E/KPT/2018 \\
\hline \hline
\end{tabular}

\title{
KEBIASAAN MAKANAN, LUAS RELUNG DAN TINGKAT TROFIK KOMUNITAS IKAN DI ESTUARI KALIWLINGI KABUPATEN BREBES
}

\section{FOOD HABITS, NICHE BREADTH AND TROPHIC LEVEL OF FISH COMMUNITY IN KALIWLINGI ESTUARYBREBES DISTRICT}

\author{
Nanang Widarmanto*1, Haeruddin ${ }^{1}$, Pujiono Wahyu Purnomo ${ }^{1}$ \\ ${ }^{1}$ Program Studi Manajemen Sumber Daya Pantai, Fakultas Perikanan dan Ilmu Kelautan,Universitas Diponegoro, \\ Jl. Prof. Soedarto,SH, Tembalang, Semarang-Jawa Tengah, Indonesia \\ Teregistrasi I tanggal: 08 September 2019; Diterima setelah perbaikan tanggal: 01 November 2019; \\ Disetujui terbit tanggal: 16 November 2019
}

\begin{abstract}
ABSTRAK
Studi mengenai kebiasaan makanan serta tingkat trofik ikan merupakan hal penting untuk mengetahui interaksi serta aliran energi antar spesies dalam ekosistem. Informasi ini membantu dalam pengelolaan ekosistem yaitu sebagai acuan dalam mengkaji perubahan yang terjadi serta bermanfaat untuk membangun model trofik dalam pengelolaan. Estuari merupakan eskosistem dinamis yang memiliki berbagai tipe jenis ikan serta rentan mengalami perubahan akibat aktivitas manusia. Pengelolaan ekosistem estuari penting untuk menjamin keberlanjutan sumberdaya ikan. Penelitian ini dilakukan di perairan estuari Kaliwlingi Brebes pada November-Desember 2018 dengan tujuan untuk mengetahui kebiasaan makanan, luas relung dan tingkat trofik komunitas ikan pada estuari Kaliwlingi. Hasil penelitian menunjukkan bahwa jenis makanan yang dimanfaatkan komunitas ikan di kawasan tersebut adalah fitoplankton, zooplankton, tumbuhan (makrofita), molusca, insekta (serangga), annelida, ikan, udang dan detritus. Beberapa ikan memiliki luas relung yang tinggi yang mengindikasikan cenderung bersifat generalis dalam memanfaatkan sumberdaya makanan. Sebagian besar ikan pada penelitian ini termasuk dalam tingkat trofik omnivora.
\end{abstract}

Kata Kunci: Kebiasaan makanan; luas relung; tingkat trofik; estuari

\section{ABSTRACT}

The study of food habit and tropic levels of fish is important for understanding interaction and energy flows among species. This information helps in management of ecosystems as reference in assessing changes that occur in ecosystems and useful for constructing trophic model. Estuary ia a dynamic ecosystem that has various types of fish and susceptible due to human activitiesEstuaries is a habitat for various fish. However, estuaries is one of the vulnerable coastal ecosystems due to human activities impact.Management for estuaries ecosystem is important to maintain fish resources sustainability. This research was conducted in Kaliwlingi estuary-Brebes district in November - Desember 2018. The aim if this research is to obtain information of food habits, niche breadth and trophic level of fish community in Kaliwlingi estuary. The results showed that the food utilized by the fishes were phytoplankton, zooplankton, plants (macrophytes), mollusc, insects, annelids, nekton (fish), shrimp and detritus. Some fishes have a broad niche breadth which indicates as generalist in utilizing food resources. The trophic level of most of the fishes found in this study is omnivorous.

Keywords: Food habits; niche breadth; trophic level; estuary

\section{PENDAHULUAN}

Estuari merupakan ekosistem di wilayah pesisir berupa perairan semi tertutup yang terkoneksi dengan laut dan perairan tawar. Estuari diketahui sebagai ekosistem yang memiliki produktivitas tinggi karena kaya akan kandungan hara. Ekosistem estuari memiliki fungsi ekologis seperti

Korespondensi penulis:

e-mail:widarmanto.n80@gmail.com

Telp. +62 813-1868-1242

DOI: http://dx.doi.org/10.15578/bawal.11.1.2019.69-78

Copyright (C) 2019, BAWAL WIDYA RISET PERIKANAN TANGKAP (BAWAL) menyediakan habitat pemijahan (spawning ground), asuhan (nursery ground) dan lumbung makanan (feeding ground) bagi berbagai jenis ikan. Berbagai fungsi ekologis tersebut menjadikan estuari kaya akan jenis ikan dalam berbagai fase hidup seperti larva, juvenile dan dewasa (Blaber, 1997). Komunitas ikan yang mendiami estuari biasanya merupakan kombinasi dari spesies air tawar, 
spesies penetap sejati estuari dan spesies dari laut. Menurut Blaber (1997), komunitas ikan pada ekosistem estuari terdiri dari spesies estuari sejati, spesies laut, spesies peruaya dari laut dan spesies peruaya dari perairan tawar yang masuk estuari melalui alur sungai.

Salah satu kawasan estuari di Brebes berada di daerah Kaliwlingi yang terletak di sebelah timur Kabupaten Brebes yang merupakan sistem muara dari sungai Pemali yang masih mendapatkan pengaruh pasang surut dari Laut Jawa serta memiliki ekosistem mangrove di sekitarnya. Kawasan ini dimanfaatkan oleh nelayan sebagai daerah penangkapan karena perairan ini menyimpan fauna ikan yang cukup beragam, terdapat sekitar 87 jenis ikan yang teridentifikasi di perairan tersebut (Nurfiarini et al., 2017).

Kebiasaan makanan (food habit) merupakan jenis-jenis makanan alami yang dimakan oleh ikan baik dari segi kuantitas maupun kualitas (Effendie, 2002). Kajian mengenai kebiasaan makanan ikan merupakan hal mendasar yang dibutuhkan menjelaskan peran jenis ikan dalam suatu ekosistem yaitu hubungan antar spesies pada komunitas tersebut dalam memanfaatkan sumber daya makanan alami dan secara tidak langsung menunjukkan aliran energi dalam ekosistem tersebut (Hajisamaea et al., 2003, Ramirez-Luna et al., 2008).

Luas relung (niche breadth) makanan menggambarkan proporsi sumber daya makanan yangdapat dimanfaatkan oleh suatu spesies. Menurut Krebs (1989), mempelajari luas relung makanan dapat membantu untuk menjelaskan posisi suatu spesies dalam rantai makanan dan menurut Segurado et al. (2011), luas relung juga dapatmenjelaskan tingkat spesialisasi makanan pada kelompok spesies tertentu. Spesies dengan luas relung yang sempit mencirikan spesies yang bersifat spesialis sedangkan spesies dengan relung yang luas biasanya merupakan spesies yang bersifat generalis dalam memanfaatkan sumber daya makanan (Oliveiraet al., 2014). Peran suatu spesies dalam ekosistem berdasarkan pemanfaatan sumber daya makanan alami menjelaskan posisi spesies tersebut dalam rantai makanan atau dikenal sebagai tingkat trofik. Tingkat trofik suatu spesies diestimasi dengan menggunakan data komposisi makanan (Pauly et al., 2000). Kajian mengenai tingkat trofik spesies ikan sangat penting dalam pengelolaan sumberdaya ikan berbasis ekosistem, salah satunya sebagaiacuan untuk mengkaji efek penangkapan ikan terhadap jejaring makanan komunitas ikan pada ekosistem perairan (Stregiou \& Karpouzi, 2002).

Estuari merupakan salah satu ekosistem pesisir yang rentan sebagai akibat pemanfaatan yang dilakukan manusia diantaranya pencemaran lingkungan akibat aktivitas antropogenik serta tekanan penangkapan terhadap komunitas ikan. Perubahan lingkungan estuari tentunya berdampak pada komunitas ikan yang ada di dalamnya termasuk dalam pemanfaatan sumber daya makanan alami yang ada, keseimbangan rantai makanan serta interaksi antar spesies ikan dalam memanfaatkan pakan alami. Upaya pengelolaan ekosistem estuari diperlukan untuk menjaga keberlanjutan sumber daya ikan. Dalam upaya pengelolaan tersebut dibutuhkan data dan informasi dasar seperti kebiasaan makanan, luas relung dan tingkat trofik komunitas ikan tersebut. Oleh karenanya, penelitian ini bertujuan untuk menganalisis kebiasaan makanan, luas relung dan tingkat trofik komunitas ikan di Estuari Kaliwlingi Kabupaten Brebes.

\section{BAHANDANMETODE}

Penelitian dilaksanakan di Estuari Kaliwlingi, Kabupten Brebes Provinsi Jawa Tengah pada bulan NovemberDesember 2018 (Gambar 1). Pengambilan sampel dilakukan sebanyak dua kali. Stasiun pengambilan sampel ditentukan secara random dengan kriteria yang dapat mewakili karakteristik lingkungan perairan estuari Kaliwlingi. Pengambilan ikan contoh dilakukan menggunakan jaring insang percobaan (ukuran 1-4 inchi dengan interval 0,5 inchi) yang dipasang pada sore hari kemudian diangkat pada keesokan pagi harinya.

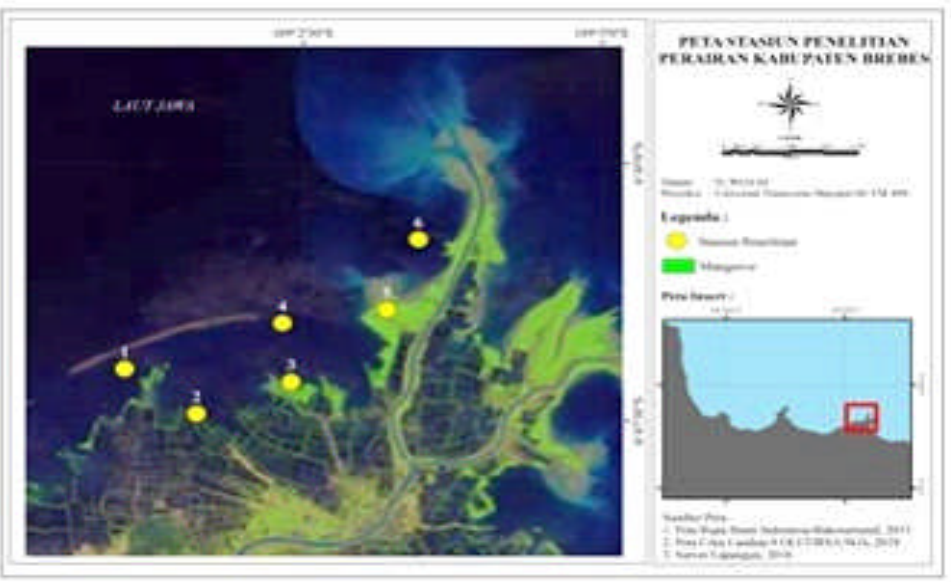

Gambar 1. Lokasi stasiun penelitian di Kaliwlingi, Kabupaten Brebes. Figure 1. Research Stationinthe Kaliwlingi estuary Brebes district. 
Identifikasi jenis ikan contoh mengacu kepada Kottelat et al. (1993), FAO Species Identification Guide For Fishery Purposes Vol 3-6 (Carpenter \& Niem, 1999) dan situs Fishbase (Froese \& Pauly, 2017). Ikan contoh yang tertangkap kemudian diukur panjang totalnya menggunakan papan ukur dengan ketelitian $0,1 \mathrm{~cm}$ dan ditimbang bobot tubuhnya menggunakan timbangan digital dengan ketelitian 0,1 gram. Ikan contoh dibedah pada bagian perut untuk diambil lambungnya. Lambung ikan dimasukkan ke dalam wadah yang diberi label dan diawetkan dengan larutan formalin $4 \%$. Pengamatan isi perut ikan dilakukan di laboratorium. Sampel ikan yang digunakan dalam analisis merupakan hasil tangkapan yang jumlahnya dominan. Makanan alami pada lambung ikan diperiksa dan diidentifikasi jenisnya menggunakan mikroskop binokuler dan stereozoom di Laboratorium Biologi, Balai Riset Pemulihan Sumberdaya Ikan. Identifikasi jenis pakan alami mengacu pada Needham \& Needham (1962), Edmonson (1978), dan Quigley (1977).

Analisis data untuk mengetahui kebiasaan makanan untuk masing-masing jenis ikan menggunakan indek bagian terbesar (index of preponderance). Indeks of preponderance merupakan gabungan dari metode frekuensi kejadian dengan metode volumetrik. Indek ini sering digunakan dalam studi kebiasaan makanan ikan dan menilai bermacam-macam makanan yang menjadi kesukaan ikan (Effendie, 1979).

Indeks of preponderance dihitung dengan menggunakan rumus perhitungan menurut Natarajan \& Jhingran, (1961).

$$
I P=\frac{V_{i} x O_{i}}{\sum_{i=1}^{n}\left(V_{i} \mathrm{XO}_{\mathrm{i}}\right)}
$$

dimana;

$\mathrm{IP}=$ index of preponderance (Indeks bagian terbesar)

$\mathrm{V}_{\mathrm{i}}=$ persentase volume makanan ikan jenis ke-i

$\mathrm{O}_{\mathrm{i}}=$ persentase frekuensi kejadian makanan jenis ke-i

Komposisi makanan dikelompokan menjadi sepuluh jenis (Hahn \& Delariva, 2003, Mérona et al., 2005, Novakowski et al., 2007 dalam Oliveira et al., 2014) yaitu: 1). Fitoplankton, 2). Zooplankton, 3). Tumbuhan (bagian daun, batang, biji-bijan), 4). Insekta, 5). Cacing (annelida dan non-annelida), 6). Moluska (bivalvia, gastropoda), 7). Udang, 8). Ikan (seluruh bagian termasuk sisik dan sirip), 9). Fraksi Hewan (tidak teridentifikasi), 10). Detritus. Menurut Oliveira et al. (2014), preferensi dan spesialisasi jenis pakan (pakan utama) dari setiap spesies yang berbeda dilakukan berdasarkan frekuensi kejadian satu macam makanan (Ii e" 50\%). Dalam kasus tertentu, dimana jumlah dari macam makanan relatif berkurang maka digunakan Ii e" 40\% (Gaspar da Luz et al., 2001 dalam Oliveira et al., 2014).
Luas relung merupakan parameter penting untuk mengevaluasi tingkat spesialisasi makanan pada kelompok spesies tertentu (Segurado et al., 2011). Luas relung dapat dihitung berdasarkan pakan yang dimanfaatkan oleh ikan menggunakan Indeks Levin (Hespenheide, 1975).

$$
B_{j}=\left(\sum \rho_{i}^{2}\right)^{-1}
$$

dimana;

$\mathrm{B}_{\mathrm{j}}=$ luas relung

$\mathrm{p}_{\mathrm{i}}=$ proposional kelompok makanan ke-i yang dikonsumsi oleh ikan ke-j

Perhitungan estimasi tingkat trofik masing-masing jenis ikan dihitung menggunakan perhitungan yang dikemukakan Pauly et al. (2000) sebagai berikut:

$$
\text { troph }=1+\sum_{j=1}^{G} D C_{i j} . \text { troph }_{j}
$$

dimana;

troph $=$ Tingkat trofik

$\mathrm{DC}_{\mathrm{ij}}=$ fraksi jenis makanan $\mathrm{j}$ dalam isi lambung pemangsa $\mathrm{i}$

troph $_{\mathrm{j}}=$ trofik level jenis makanan $\mathrm{j}$

$\mathrm{G}=$ jumlah kelompok makanan dalam lambung pemangsa $\mathrm{i}$

Perhitungan dilakukan dengan program TrophLab (Pauly et al., 2000). Stergiou \& Karpouzi (2002) mengkategorikan nilai tingkat trofik (troph) sebagai berikut:

$$
\begin{aligned}
2,0-2,1= & \text { herbivora } \\
2,1<\text { troph }<2,9= & \text { omnivora dengan preferensi } \\
& \text { makanan tumbuhan } \\
2,9<\operatorname{troph}<3,7= & \text { omnivora dengan preferensi } \\
& \text { makanan hewani } \\
3,7<\text { troph }<4,5= & \text { karnivora }
\end{aligned}
$$

\section{HASIL DAN BAHASAN \\ Hasil}

Sebanyak 249 ekor ikan yang terdiri dari 30 jenis dan termasuk ke dalam 26 famili berhasil diperoleh dalam penelitian ini. Jenis ikan yang dominan tertangkap terdiri dari 13 jenis (Tabel 1), dimana ikan kiper (Scatophagus argus) dan belanak (Planiliza subviridis) merupakan jenis ikan yang paling dominan.

Hasil analisis kebiasaan makanandilakukan terhadap 13 jenis ikan dominan yang dianggap mewakili komunitas ikan di perairan tersebut. Jenis makanan yang dimanfaatkan oleh komunitas ikan terdiri dari fitoplankton, zooplankton, tumbuhan (makrofita), molusca, insekta (serangga), annelida, ikan, udang dan detritus. Komposisi makanan komunitas ikan di estuari Kaliwlingi tertera pada Gambar 2. 
Tabel 1. Jenis ikan dominan yang tertangkap di estuari Kaliwlingi

Table 1. The dominant fish species caught in the Kaliwlingi estuary

\begin{tabular}{cllcc}
\hline No. & Nama lokal & \multicolumn{1}{c}{ Nama Ilmiah } & $\begin{array}{c}\text { Jumlah } \\
\text { (ekor) }\end{array}$ & KR (\%) \\
\hline 1 & Kiper & Scatophagus argus & 82 & 32.93 \\
2 & Belanak & Planiliza subviridis & 60 & 24.10 \\
3 & Kerong-kerong & Terapon jarbua & 11 & 4.42 \\
4 & Kada & Crenimugil cunnensis & 9 & 3.61 \\
5 & Kedukang & Hexanematichthys sagor & 9 & 3.61 \\
6 & Kuro & Eleutheronema tetradactylum & 7 & 2.81 \\
7 & Kutik & Arius maculatus & 7 & 2.81 \\
8 & Belama & Nibea soldado & 7 & 2.81 \\
9 & Semadar & Siganus javus & 6 & 2.81 \\
10 & Selok & Sardinella gibbosa & 5 & 2.41 \\
11 & Belanak Jebug & Moolgarda buchanani & 5 & 2.01 \\
12 & Itek-itek & Grammoplites scaber & 5 & 2.01 \\
13 & Ilat & Cynoglossus lingua & 5.01 \\
\hline
\end{tabular}

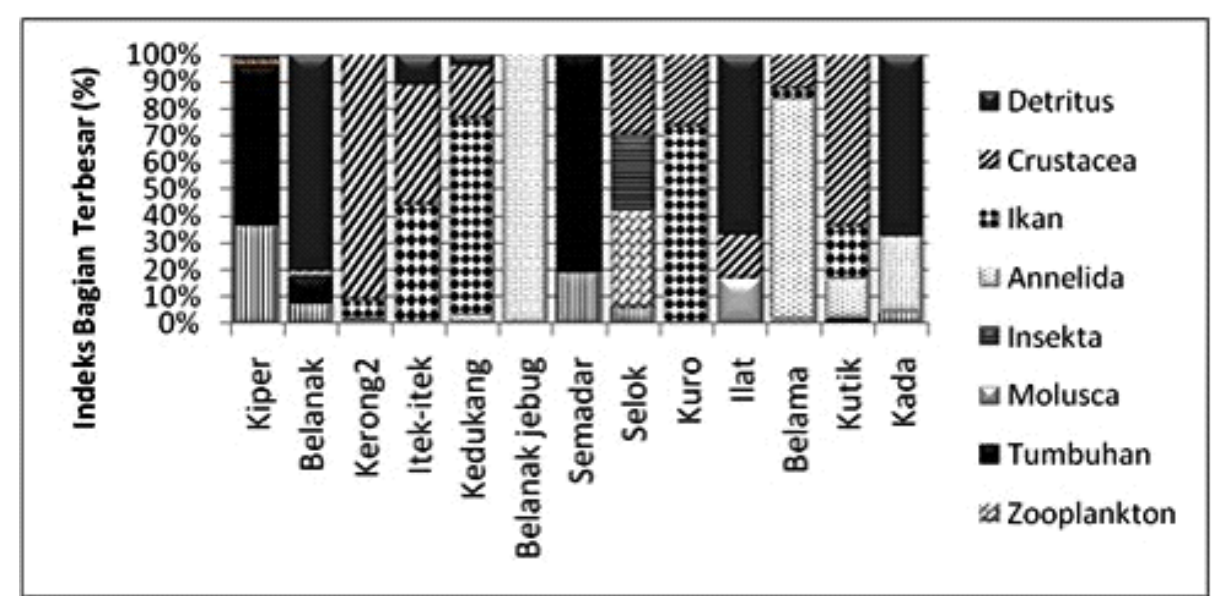

Gambar 2. Kebiasaan makanan ikan di estuari Kaliwlingi.

Figure 2. Feeding habits of fish in the Kaliwlingi estuary.

Luas relung komunitas ikan di Estuari Kaliwlingi pada penelitian ini berkisar antara 1,00- 3,36 (Tabel 2). Ikan belanak jebuk memiliki luas relung paling rendah sedangkan ikan selok (Sardinella gibbosa) memiliki luas relung paling tinggi.

Tabel 2. Luas relung komunitas ikan di Estuari Kaliwlingi

Table 2. Niche beadth of fish comunity in the Kaliwlingi estuary

\begin{tabular}{cllc}
\hline No & \multicolumn{1}{c}{ Ikan } & \multicolumn{1}{c}{ Nama Latin } & Luas relung $\left(\mathbf{B}_{\mathbf{j}}\right)$ \\
\hline 1 & Belanak jebug & Moolgarda buchanani & 1.00 \\
2 & Kerong-kerong & Terapon jarbua & 1.20 \\
3 & Belama & Nibea soldado & 1.45 \\
4 & Semadar & Siganus javus & 1.46 \\
5 & Belanak & Planiliza subviridis & 1.51 \\
6 & Kuro & Eleutheronema tetradactylus & 1.64 \\
7 & Kada & Crenimugil cunnensis & 1.86 \\
8 & Ilat & Cynoglossus lingua & 2.00 \\
9 & Kiper & Scatophagus argus & 2.02 \\
10 & Itek-itek & Grammoplites scaber & 2.45 \\
11 & Kedukang & Hexanematichthys sagor & 2.89 \\
12 & Kutik & Arius maculatus & 3.03 \\
13 & Selok & Sardinella albela & 3.36 \\
\hline
\end{tabular}


Berdasarkan analisis luas relung makanan, secara kualitatif jenis ikan dalam komunitas ikan di Estuari Kaliwlingi dapat dikelompokkan dalam tiga kelompok besar (Gambar 3), yaitu:

1) Kelompok I adalah ikan herbivora yang terdiri dari ikan Semadar, Belanak dan Kiper. Kelompok ini memiliki luas relung antara 1,46-2,02. Pada penelitian ini, ikan yang memiliki luas relung kecil cenderung bersifat herbivora. Kelompok ini cukup spesialis dalam memanfaatkan sumber daya makanan di alam.

2) Kelompok II adalah ikan omnivora dengan preferensi makanan tumbuhan (IIA) dan kelompok omnivora dengan preferensi makanan hewani (IIB). Jenis ikan yang termasuk kelompok IIA adalah ikan Kada, dan Ilat. Sedangkan jenis ikan yang termasuk dalam kelompok IIB adalah ikan Kedukang, Belanak jebung,
Belama, Selok, Kerong-kerong, dan Kutik. Kelompok omnivora (II) ini memiliki nilai luas relung antara 13,36. Kelompok ini memiliki luas relung yang cukup luas dan cenderung bersifat generalis dalam memanfaatkan makanan yang tersedia di alam. Dengan luas relung yang cukup luas, diperkirakan kelompok ini adaptif terhadap perubahan ketersedian makanan alami yang terdapat di perairan.

3) Kelompok III adalah ikan dalam kelompok karnivora yang terdiri dari ikan Itek-itek dan Kuro. Dari nilai luas relung menunjukkan ikan itek-itek memiliki luas relus $(\mathrm{Bj}=2,45)$ lebih besar dari ikan kuro $(\mathrm{Bj}=1,64)$. Hal tersebut menunjukkan bahwa Itek-itek lebih bersifat generalis daripada ikan Kuro, dengan kata lain bahwa ikan Itek-itek dapat beradaptasi lebih terhadap perubahan ketersediaan makanan di alam daripada ikan Kuro.

Tabel3. Tingkat Trofik Jenis Ikan di Estuari Kaliwlingi Table 3. Tropic level of fish species in the Kaliwlingi estuary

\begin{tabular}{|c|c|c|c|c|}
\hline No. & Jenis Ikan & Nama Latin & Troph & Tingkat Trofik \\
\hline 1. & Kiper & Scatophagus argus & 2.0 & herbivora \\
\hline 2. & Belanak & Planiliza subviridis & 2.0 & herbivora \\
\hline 3. & Kerong-kerong & Terapon jarbua & 3.7 & $\begin{array}{l}\text { Omnivora dengan preferensi makanan } \\
\text { hewani }\end{array}$ \\
\hline 4. & Itek-itek & Grammoplites scaber & 3.8 & Karnivora/piscivora \\
\hline 5. & Kedukang & Hexanematichthys sagor & 4.2 & Karnivora hewani / piscivora \\
\hline 6. & Belanak jebug & Crenimugil buchanani & 3.0 & $\begin{array}{l}\text { Omnivora dengan preferensi makanan } \\
\text { hewani }\end{array}$ \\
\hline 7. & Semadar & Siganus javus & 2.0 & herbivora \\
\hline 8. & Selok & Sardinella gibbosa & 2.7 & $\begin{array}{l}\text { Omnivora dengan preferensi makanan } \\
\text { material sisa tumbuhan tumbuhan }\end{array}$ \\
\hline 9. & Kuro & Eleutheronema tetradactylus & 4.3 & Karnivora/ piscivora \\
\hline 10. & Ilat & Cynoglossus lingua & 2.5 & $\begin{array}{l}\text { Omnivora dengan preferensi makanan } \\
\text { material sisa tumbuhan dan } \\
\text { invertebrata }\end{array}$ \\
\hline 11. & Belama & Nibea soldado & 3.2 & $\begin{array}{l}\text { Omnivora dengan preferensi makanan } \\
\text { hewani (Annelida) }\end{array}$ \\
\hline 12. & Kutik & Arius maculatus & 3.8 & $\begin{array}{l}\text { Karnivora dengan preferensi makanan } \\
\text { hewani (Crustacea) }\end{array}$ \\
\hline 13. & Kada & Osteomugilcunnensis & 2.3 & $\begin{array}{l}\text { Omnivora dengan preferensi makanan } \\
\text { material sisa tumbuhan }\end{array}$ \\
\hline
\end{tabular}

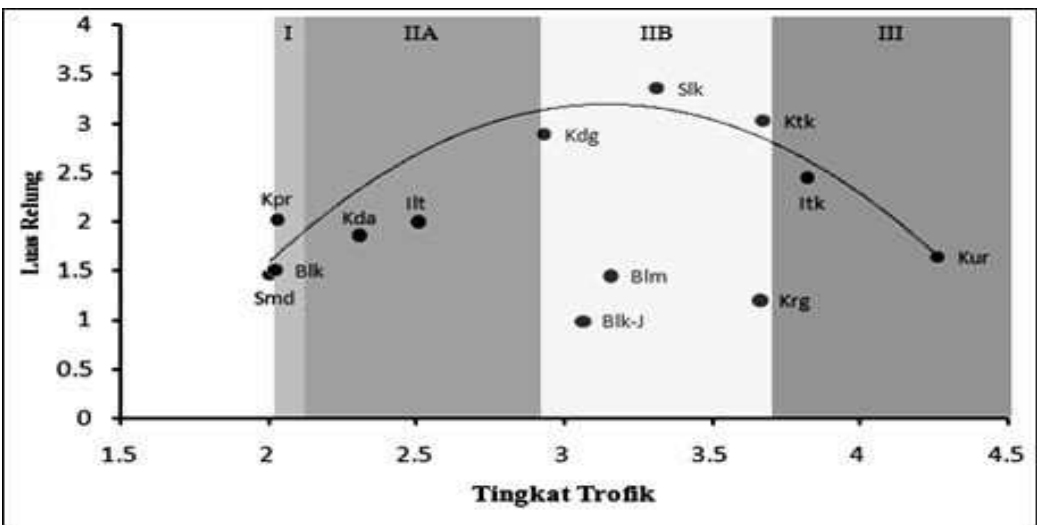

Gambar3. Hubungan tingkat trofik dengan luas relung ikan di Estuari Kaliwlingi.

Figure 3. Relationship beetwen Trophic level and niche breadth of fish in the Kaliwlingi estuary. 


\section{Bahasan}

Ikan kiper (Scatophagus argus) di estuari Kaliwilingi memanfaatkan makanan alami berupa tumbuhan (makrofita), fitoplankton, zooplankton, ikan, annelida, crustacea, dan detritus. Dalam hal ini, tumbuhan dikategorikan sebagai makanan utamanya. Hal yang sama dilaporkan oleh Tjahjo et al. (2012) di estuari Segara Anakan yang menyebutkan bahwa ikan kiper memiliki makanan utama berupa tumbuhan dan fitoplankton. Hal yang serupa juga ditemukan pada hasil penelitian Sivan \& Radhakrishnan (2011). Sedangkan menurut Allen (1984) ikan kiper memakan cacing, crustacea, serangga dan tanaman.

Ikan famili Mugilidae yaitu belanak (Planiliza subviridis) dan kada (Osteomugil cunnesius)yang diperoleh pada penelitian ini memakan kelompok jenis makanan yang sama yaitu detritus.Secara detil komposisi makanan ikan belanak pada penelitian ini terdiri atas detritus, tumbuhan, fitoplankton, zooplankton, annelida dan crustacea, dimana detritus dikategorikan sebagai makanan utama. Sementara itu komposisi makanan ikan kada terdiri atas detritus, annelida, dan fitoplankton. Dalam hal ini, kedua jenis ikan tersebut memiliki kesamaan jenis makanan yaitu kelompok detritus dan annelida. Sedangkan jenis makanan alami yang teridentifikasi pada famili Mugilidae lainnya yaitu belanak jebug (Crenimugil buchanani) berupa kelompok zoobentho yaitu annelida. Menurut Harrison dan Senou (1997), ikan Crenimugil buchanani memakan fitoplankton, tumbuhan, polychaeta dan crustacea kecil. Detritus dan annelida dapat dikategorikan sebagai makanan utama ikan famili Mugilidae pada penelitian ini. Hal ini cenderung serupa dengan hasil beberapa penelitian lainnya di lokasi yang berbeda dimana jenis pakan alami yang utama adalah detritus (Tse et al., 2008; Pasquaud et al., 2010).

Komposisi makanan ikan kerong-kerong (Terapon jarbua) yaitu crustacea, ikan, tumbuhan, moluska, dan serangga, dengan Crustacea dalam hal ini teridentifikasi sebagai udang kecil merupakan makanan utama. Komposisi makanan ikan kerong-kerong di estuari Kaliwlingi serupa dengan hasil penelitian yang dilakukan oleh Manoharan et al. (2012) di perairan estuari Parangipettai, India, sedangkan menurut Vari (2001) makanan ikan ini adalah ikan kecil dan invertebrate. Ikan ini dikategorikan sebagai euryphagous karnivor yang memiliki preferensi makanan cukup luas mulai dari oragnisme planktonik hingga bentik Manoharan et al. (2012)

Komposisi jenis makanan ikan itek-itek (Grammoplites scaber) pada penelitian initerdiri ikan, crustacea, dan detritus, dimana ikan dikategorikan sebagai makanan utama. Menurut Simanjuntak \& Zahid (2009), jenis makanan ikan Grammoplites scaber di pantai Mayangan adalah kelompok crustacea, ikan, cephalopoda, dan bivalva.

Komposisi makanan ikan ilat (Cynoglossus lingua) di estuari Kaliwlingi yaitu detritus, kelompok Crustacea berupa udang kecil dan annelida, dengan makanan utama berupa detritus. Menurut Munroe (2001), Cynoglossus lingua merupakan ikan demersal yang makanan utamanya berupa invertebrata bentik sedangkan hasil penelitian Sulistiono et al., (2009) terhadap ikan tersebut di pantai Ujung Pangkah Gresik menunjukkan bahwa makanan utamanya udang dan makanan pelengkapnya bivalva serta kepiting.

Makanan alami ikan selok (Sardinella gibbosa) yang ditemukan pada penelitian ini adalah zoobenthos berupa crustacea dan insekta (isopoda) serta zooplankton (kelompok Copepoda) sebagai makanan utama serta, fitoplankton dan detritus sebagai makanan tambahan lainnya.Menurut Nyunja et al. (2002), ikan Sardinella gibbosa merupakan jenis ikan yang memakan kelompok zooplankton seperti copepoda.

Ikan kuro atau senangin (Eleutheronema tetradactylum) memanfaatkan makanan alami berupa ikan dan udang. Menurut hasil penelitian Titrawani et al. (2013), jenis makanan ikan kuro yang ditangkap di perairan Dumai adalah kelompok Crustacea, ikan, cacing dan detritus, demikian pula menurut Bogarestu (2012), yang mengemukakan bahwa ikan kuro yang diteliti dari perairan Mayangan memanfaatkan kelompok Crustacea berupa udang Penaeus, ikan dan kepiting sebagai makanannya.

Ikan semadar (Siganus javus) memanfaatkan makanan alami berupa tumbuhan (makrofita) dan fitoplankton. Hasil penelitian yang dilakukan Perpetuaet al. (2013), menunjukkan komposisi makanan ikan Siganus javus di perairan Minadanao, didominasi oleh alga dan lamun, serta sebagian kecil detritus.

Ikan kedukang (Hexanematichthys sagor) dan ikan kutik (Arius maculate) merupakan famili Ariidae yang terdapat di perarian estuari Kaliwlingi. Jenis makanan keduanya hampir sama yaitu nekton (ikan) dan udang. Komposisi makanan ikan kedukang berupa ikan dan udang dimana ikan menjadi makanan utamanya, sedangkan makanan ikan kutik berupa udang sebagai makanan utamanya dan udang serta detritus sebagai makanan lainnya.

Komposisi makanan ikan Belama (Nibea soldado) didominasi kelompok zoobenthos yaitu cacing annelida dan sebagian kecil organisme bentik kelompok Crustacea. Hal ini serupa dengan hasil penelitian Jeyaraj et al. (2015), terhadap ikan Nibea soldadodi perairan Keralla, India. 
Perbedaan kebiasaan makanan dapat dipengaruhi oleh perbedaan struktur anatomis organ-organ pencernaan (Lagler et al., 1977; Effendie, 2002). Komposisi pakan ikan sangat dipengaruhi oleh musim dan lokasi (Medeiros \& Arthington, 2008). Menurut Lammens \& Hoogenboezem (1981), saluran pencernaan ikan telah disesuaikan dengan makanan yang dikonsumsi oleh ikan tersebut, agar proses mencerna makanan dapat berlangsung optimum. Rahardjo et al. (2011) menyebutkan bahwa variasi jenis organisme makanan yang dimakan ikan juga dapat mengkategorikan ikan menjadi kelompok monofagus (ikan yang makanannya hanya terdiri dari satu jenis organisme makanan), stenofagus (ikan yang makanannya terdiri atas beberapa jenis organisme makanan), dan eurifagus (ikan yang makanannya terdiri atas berbagai jenis organisme makanan atau variasi jenis makannnya tinggi).Ikan belanak jebug dikategorikan sebagai kelompok monofagus.Ikan itek-itek, semadar, kuro, ilat, dan kada dapat dikategorikan sebagai kelompok stenofagus dimana hanya memiliki beberapa jenis makanan (tiga jenis makanan). Sedangkan ikan kiper, belanak, kerong-kerong, kedukang, selok, belama dan kutik yang memiliki variasi makanan tinggi (4-10 jenis organisme makanan) dapat dikategorikan sebagai kelompok ikan eurifagus.

Berdasarkan analisa luas relung, ikan yang memiliki luas relung rendah memiliki variasi makanan yang sedikit. Hal ini menunjukkan bahwa ikan tersebut cenderung bersifat selektif terhadap sumber daya makanan yang terdapat di perairan. Ikan yang memiliki luas relung makanan yang kecil atau sempit menandakan bahwa ikan tersebut melakukan seleksi terhadap sumber daya makanan yang tersedia di perairan (Krebs, 1989). Pada penelitian ini ikan belanak jebuk, kerong-kerong, semadar, belama, belanak, dan kuro termasuk jenis ikan dengan luas relung yang rendah.

Sedangkan ikan yang memiliki luas relung yang lebih tinggi seperti ikan kutik, dan selok cenderung memiliki variasi makanan yang lebih banyak. Hal tersebut menunjukkan ikan kutik dan selok cenderung bersifat generalis dalam memanfaatkan sumber daya makanan di alam. Ikan kutik yang dikategorikan ikan karnivora memakan jenis organisme hewani yang beragam seperti crustacea, annelida dan nekton (ikan), sedangkan ikan selok memanfaatkan jenis makan dari kelompok crustacean, zooplankton dan serangga air.

Nilai luas relung yang semakin besar menunjukkan pola makanan ikan bersifat generalis dan tidak selektif terhadap organisme yang dimakan, sedangkan luas relung yang kecil mencirikan ikan lebih selektif dalam memilih makanannya (Colwell \& Futuyama, 1971). Selanjutnya, Lagler (1972) menyatakan bahwa tidak semua jenis sumber daya makanan yang terdapat pada suatu perairan akan disukai oleh ikan, namun tergantung dari selera ikan terhadap makanan, ukuran makanan, dan ketersediaan makanan di alam. Tse et al. (2008) menambahkan bahwa luas relung ikan cenderung meningkat ketika ketersediaan makanan rendah dan cenderung menurun ketika ketersediaan makanan tinggi.

Pada penelitian ini, ikan-ikan yang memiliki luas relung kecil (belanak jebug, itek-itek, kuro, semadar, dan ilat) ternyata memiliki variasi beberapa macam jenis organisme makanan (stenofagus) dimana hanya memiliki variasi 3 jenis organisme makanan. Sedangkan ikan lainnya yang memiliki luas relung tinggi memiliki variasi jenis organisme makanan yang cukup tinggi (eurifagus) yan memiliki variasi 4-10 jenis organisme makanan.

Hasil analisis kebiasaan makanan dilanjutkan dengan analisis tingkat trofik terhadap jenis-jenis ikan yang diamati. Hasil analisis diperoleh rentang tingkat trofik komunitas ikan mulai 2,02-4,26 (lihat Tabel 3). Stergiou \& Karpouzi (2002) mengkategorikan nilai tingkat trofik (troph) menjadi empat kelompok yaitu kelompok herbivora (troph $=2,0-2,1)$; omnivora dengan preferensi makanan sisa tumbuhan serta invertebrata $(2,1<$ troph $<2,9)$; omnivora dengan preferensi makanan hewani $(2,9<$ troph $<3,7)$, dan karnivora $(3,7<$ troph $<4$, .

Kelompok ikan dengan nilai tingkat trofik 2,00-2,03 berperan sebagai herbivora yaitu ikan kiper, belanak dan semadar.Ketiga ikan tersebut memiliki kesamaan makanan utama berupa fitoplankton, tumbuhan dan detritus.Sebagai ikan herbivora, ikan kiper dan belanak memiliki kelimpahan yang tertinggi pada perairan Estuari Estuari Kaliwlingi. Nontji (2006) menjelaskan bahwa ikan dengan tingkat trofik rendah membutuhkan energi yang kecil untuk memperoleh makanannya dan dapat tumbuh dengan jumlah yang lebih banyak.Kelimpahan yang tinggi pada ikan herbivora, terutama ikan kiper dan belanak dengan makanan utama tumbuhan didukung dengan keberadaan vegetasi mangrove yang menyediakan sumber makanan bagi ikan-ikan tersebut.

Kelompok ikan omnivora dengan preferensi makanan material tumbuhan dan invertebrata(nilai tingkat trofik 2,32,7) terdiri dari ikan ilat (Cynoglossus puncticeps), selok (Sardinella gibbosa) dan kada.Tingkat trofik omnivora dengan preferensi makanan hewani seperti kelompok Crustacea, annelida(nilai tingkat trofik 3,0-3,8) terdiri dari ikan kerong-kerong, belanak jebug, kutik, dan belama.

Tingkat trofik karnivora dengan nilai tingkat trofik 3,84,3 terdiri dari ikan itek-itek, kuro, dan kedukang. Kelompok karnivora masih dapat dibedakan lagi menjadi (1) kelompok piscivora yaitu ikan dengan makanan utama nekton (ikan) seperti itek-itek, kedukang, kuro dan (2) kelompok krustasivora yaitu pemakan Crustacea seperti ikan kutik.

Tingkat trofik pada ikan dapat mengalami perubahan 
dengan bertambahnya ukuran individu ikan (Tse et al., 2008; Pasquaud et al., 2010).Sebagaian besar ikan yang diperoleh pada penelitian ini termasuk ikan omnivora. Menurut Ley et al. (1994), ikan di kawasan estuari sering dicirikan sebagai omnivora, berbagi sumber daya makanan yang ada, dan fleksibel.

\section{KESIMPULAN}

Jenis makanan yang dimanfaatkan oleh komunitas ikan terdiri dari fitoplankton, zooplankton, tumbuhan (makrofita), molusca, insekta (serangga), annelida, ikan, udang dan detritus. Sebagian besar ikan di estuari Kaliwlingi merupakan ikan yang bersifat generalis dalam memanfaatkan sumber daya makananalami. Sebagaian besar ikan yang diperoleh pada penelitian ini termasuk dalam tingkat trofik omnivora.

\section{DAFTAR PUSTAKA}

Allen, G. R. (1984). Scatophagidae. In Fischer, W., \& Bianchi, G (eds), FAO Species Identification Sheets for Fishery Purpose: Western Indian Ocean (Fishing Area 51). Volume 4. FAO. Rome

Blaber, S. J. M. (1997). Fish and fisheries of tropical estuaries (p. 367). Chapman and Hall, London.

Bogarestu, S. S. (2012). Variasi makanan ikan kuro (Eleutheronema tetradcatylum) terkait perubahan ukuran panjang dan musim di Pantai Mayangan, Jawa Barat. Skripsi. IPB.

Carpenter, K.E., \& Niem, V.H. (1999). The living marine resources of the western centralpacific. Volume 4. Bony Fishes Part 2 (Mugilidae to Carangidae). Rome, FAO. 2069-2790.

Colwell, R. K., \& D. J. Futuyma. (1971). On the measurement of niche breadth and overlap. Ecology. $52(4), 567-576$.

Edmonson, W. T (1978). Fresh-water Biology (Second Edition). New York, N.Y. Wiley. 1247 hlm.

Effendie, M. I. 1979. Metode biologi perikanan. Yayasan Dewi Sri. Bogor. 112 p.

Effendie, M. I. (2002). Biologi perikanan (p.163). Yayasan Pustaka Nusatara. Yogyakarta.

Froese, R., \& D. Pauly. (2017). FishBase. World Wide Web Electronic Publication. www.fishbase.org.
Hajisamaea, S., Choua, L. M., \& Ibrahim, S. (2003). Feeding habits and trophic organization of thefish community in shallow waters of an impacted tropical habitat estuarine. Coastal and Shelf Science, 58, 89-98.

Hespenheide, H.A. (1975). Prey characteristics and predator niche width. InCody, M. L., \& Diamond, J. M. Ecology and Evolution of Communities. The Belknap Press of Harvard University Press Cambridge. p. $158-179$.

Jeyaraj, N., Suhaila, A., Divya, L., Baskaran, N., Santhanam, P., \& Ravikumar, S. (2015). Foraging behavior patterns of four selected commercially important fish species in Kasaragod District, Northwest Part of Kerala. Indo-Asian Journal of Multidisciplinary Research (IAJMR). Volume - 1; Issue - 1

Kottelat, M., Whitten A. J., Kartikasari, S. N., \& Wiroatmodjo, S. (1993). Freshwater Fishes of Western Indonesia and Sulawesi. Edisi Dwi Bahasa Inggris Indonesia. Periplus Edition (HK) Ltd. Jakarta.

Krebs, C. J. (1989). Ecological methodology (p. 652). Harper and Row Inc. Publisher. NewYork.

Lagler, K. F. (1972). Freshwater fishery biology (p. 421). Second Edition. WMC Brown Company. Dubuque, London.

Lagler, K. F., Bardach, J. E., Miller, R. R., \& Passino, D.R.M. (1977). Ichtiology (p.506). John Wiley \&Sons. Inc. London.

Lammens, E. H. R. R., \& Hoogenboezem, W. (1981). Diets and feeding behavior. In Winfield, I.J., \& Nelson J. S.Cyprinid Fishes: Systematics, Biology, and Exploitation. Chapman \&Hall. London. 353-376.

Ley, J.A., Montague, C.L., \& Mcivor, C.C. (1994). FoodHabits of Mangrove Fishes-: Comparison Along Estuarine Gradients in Northeastern Florida Bay. Bulletin of Marine Science,54, 881-899.

Ramirez-Luna, V., Navia, A. F., \& Rubio, E.A. (2008). Food habits and feeding ecology of an estuarine fish assemblage of Northern Pacific Coast of Ecuador. PanAmerican Journal of Aquatic Sciences, 3(3), 361-372.

Manoharan, J., Gopalakrishnan, A., Varadharajan, D., Thilagavathi, B., \& Priyadharsini, S. (2012). Stomach content analysis of Terapon Jarbua (Forsskal) From Parangipettai Coast, South East Coast of India. Applied Science Research, 3 (5), 26052621.www.pelagiaresearchlibrary.com 
Medeiros, E. S. F., \& Arthington, A. H. (2008). Diel variation in food intake and diet composition of three native fish species in floodplain lagoons of the macintyre river, Australia. Journal of Fish Biology. 73(4), 1024-1032. https://doi.org/10.1111/j.10958649.2008.01959.x

Munroe, T.M. (2001). Cynoglossidae. In K. E. Carpenter, dan V. H. Niem, FAO Species Identification Guide For Fishery Purposes: The Living Marine Resources of the Western Central Pacific, 6, 3899. Rome: FAO.

Natarajan, A.V., \& Jhingran, A.G. (1961). Index of preponderance - a method of grading the food elements in the stomach analysis of fishes. Indian J. Fish. 8(1), 54-59.

Needham, J.G, \& Needham, P.R. (1962). A guide to the study of the freshwater biology (p. 108). HoldenDey Inc., San Francisco.

Nontji, A. (2006). Tiada kehidupan di bumi tanpa keberadaan plankton (p. 248). Lembaga Ilmu Pengetahuan Indonesia Pusat Penelitian Oseanologi, Jakarta.

Nurfiarini, A., Nastiti S.A., Syam,RA., Mujiyanto, Suryandari, A., Wijaya, D. (2017). Penelitian Pengelolaan Dan Rehabilitasi Sumberdaya Perikanan di KawasanEstuari Pantai Utara Jawa. Balai Riset Pemulihan Dan Konservasi Sumber Daya Ikan.Kementerian Kelautan Dan Perikanan.

Nyunja, J.A., Mavuti, K.M., \& Wakwabi, E.O. (2002). Trophic Ecology of Sardinella gibbosa (Pisces: Clupeidae) and Atherinomorous lacunosus (Pisces: Atherinidae) in Mtwapa Creek and Wasini Channel, Kenya.WesternIndian Ocean J. Mar. Sci. 1(2), 181-189.

Oliveira, J. C., Angelini, R., \& Isac-Nahum, V. J. (2014). Diet and niche breadth and overlap in fish communities within the area affected by an Amazonian Reservoir Apama, Brazil. Anais da Academia Brasileira de Ciências. 86(1), 383-350.

Pasquaud, S., Pillet, M., David, V., Sautour, B., \& Elie, P. (2010). Determination of fish trophic levels in an estuarine system. Estuarine, Coastal and Shelf Science, 86, 237-246.
Pauly, D., Froese, R., Sa-aP., Palomares, M.L., Christensen, V., \& Rius, J. (2000). Trophlab manual. ICLARM, Manila.

Pauly, D., Christensen, V., Froese, R., \& Palomares, M.L. (2000). Fishing down aquatic food webs. American Scientist. 88, 46-51.

Perpetua, M.D., Gorospe, J.G., Torres, M.A.J., \& Demayo, C.G. (2013). Diet composition based on stomach content of the streaked spinefoot (Siganus javus) from Three Coastal Bays in Mindanao, Philippines. Bioflux, 5(1). http://www.aes.bioflux.com.ro

Quigley, M. (1977). Invertebrates of streams and rivers, a key to identification. Edward Arnold Ltd. 25 Hill Street. London. 1-79

Rahardjo, M.F., Sjafei, D.S.,Affandi, R.,Sulistiono., \& Hutabarat, J. (2011). Ikhtiology (p. 396). Penerbit Lubuk Agung, Bandung.

Segurado, P., Santos, J.M., Pont, D., Melcher, A.H., Jalon, D.G., Hughes, R.M., \& Ferreira, M.T. (2011). Estimating species tolerance to human perturbation. Expert Judgment Versus Empirical Approaches. Ecological Indicators. 11, 16231635.DOI:.org/10.1016/ j.ecolind.2011.04.006.

Simanjuntak, C.P.H., \& Zahid A. (2009). Kebiasaan makanan dan perubahan ontogenik makanan ikan bajibaji (Grammoplites scaber) di Pantai Mayangan, Jawa Barat. Jurnal Iktiologi Indonesia, 9(1), 6373.DOI: 10.32491/jii.v9i1.202

Sivan, G., \& Radhakrishnan, C. (2011). Food, feeding habits and biochemical composition ofScatophagusargus.Turkish Journal of Fisheries and Aquatic Sciences 11: 603-608.DOI: 10.4194/13032712-v11_4_14.

Stergiou K.I. \& Karpouzi, V.S. (2002). Feeding habits and trophic levels of mediterranean fish. Reviews in Fish Biology and Fisheries, 11, 217-254. DOI: 10.1023/ A:1020556722822

Titrawani, Elvyra, R., \& Sawalia, R.U. (2013). Analisis isi lambung ikan senangin (Eleutheronema tetradactylum) di Perairan Dumai.Al-Kauniyah. Jurnal Biologi. 6(2), 85-90. https://doi.org/10.15408/alkauniyah.v6i2.2823 
Tse, P., Nip, T.H.M., \& Wong, C.K. (2008). Nursery function of mangrove: a comparison with mudflat in terms of fish species composition and fish diet. Estuarine, Coastal and Shelf Science.80, 235-242. DOI: 10.1016/j.ecss.2008.08.002
Vari, R.P., (2001). Teraponidae. In K. E. Carpenter, and V. H. Niem, FAO Species Identification Guide For Fishery Purposes The Living Marine Resources Of The Western Central Pacific.5, 3623-3625. 